\title{
Çocuklarda Ağır Astım, Biyolojik Tedaviler ve COVID-19 Pandemisinde Güncel Yaklaşımlar
}

\section{Severe Asthma, Biological Treatments in Children and Current Approaches in the COVID-19 Pandemic}

\author{
Ayșegül ERTUĞRUL, İlknur BOSTANCI
}

SBÜ Dr. Sami Ulus Kadın Doğum ve Çocuk Sağlığı Hastalıkları Eğitim ve Araştırma Hastanesi, Çocuk Immünoloji ve Alerji Bilim Dalı, Ankara, Türkiye

\section{öz}

Astım, çocukluk çağında gözlenen en sık kronik hastalıktır. Ağır astım, çocuklarda daha nadir görülen bir durumdur. Ağır astımda farkı mekanizmalar rol oynadığı için farkı fenotipler söz konusu olup tedavi hastaya göre kişiselleştirilmelidir. Hastanın ağır astım fenotipine katkıda bulunan faktörlerin değerlendirilmesi sonucunda, tip 2 astım olduğu belirlenen hastalara biyolojik tedavilerin uygulaması günümüzde ağır astım tedavisi yönetiminde önemli bir gelişme sağlamıştır. COVID-19 pandemisi sırasında güncel rehberler, biyolojik ajan uygunluk kriterlerini karșılayan ve bu tedavilerin etkili olduğu hastalarda biyolojik tedavilerin uygulanmasına devam edilmesini önermektedir. Aktif SARS-CoV-2 enfeksiyonu durumunda klinik düzelme sağlanana kadar biyolojik tedavi durdurulmalıdır.

Anahtar Sözcükler: Ağır astım, Biyolojikler, COVID-19, Çocuk

\begin{abstract}
Asthma is the most common chronic disease observed in children. Severe asthma is a relatively rare condition in children. As different mechanisms play role in severe asthma, there are different phenotypes and treatment should be individualized. The utilization of biological treatments to patients identified to have type 2 asthma, according to the evaluation of the factors that contribute to the patient's asthma phenotype, has led to a significant improvement in the management of severe asthma treatment today. During the COVID-19 pandemic, current guidelines recommend continuing the biological treatments to the patients meeting biological agent usage criteria and to whom these treatments are effective. In case of active SARS-CoV-2 infection, biological therapy should be stopped until clinical improvement is achieved.
\end{abstract}

Key Words: Severe asthma, Biologicals, COVID-19, Child

(10)

ERTUĞRUL A : 0000-0002-8146-3386 BOSTANCI I : 0000-0001-6392-5877
Çıkar Çatışması: Tüm yazarlar adına, ilgili yazar çıkar çatışması olmadığını belirtir.

Conflict of Interest: On behalf of all authors, the corresponding author states that there is no conflict of interest.

Yazarların katkısı / Contribution of the Authors: ERTUĞRUL A: Araștırma ve/veya makalenin hipotezini veya fikrini olușturan, Sonuçlara ulașmak için planlama/ metodoloji belirleme, Araștırma/çalıșmanın sorumluluğunu üstlenmek, ilerlemenin seyrini denetlemek, Hasta takibinde sorumluluk almak, ilgili biyolojik malzemelerin toplanması, veri yönetimi ve raporlama, deneylerin yürütülmesi, Sonuçların mantıksal olarak yorumlanması ve sonuçlandırılması, Çalışma için gerekli literatür taramasında sorumluluk almak, Çalıșmanın bütününün veya önemli bölümlerinin yazımında sorumluluk almak, Yazım ve dilbilgisi dışında bilimsel olarak gönderilmeden önce makaleyi gözden geçirme. BOSTANCI i: Araştırma ve/veya makalenin hipotezini veya fikrini oluşturan, Sonuçlara ulaşmak için planlama/metodoloji belirleme Araștırma/çalıșmanın sorumluluğunu üstlenmek, ilerlemenin seyrini denetlemek, Hasta takibinde sorumluluk almak, ilgili biyolojik malzemelerin toplanması, veri yönetimi ve raporlama, deneylerin yürütülmesi, Sonuçların mantıksal olarak yorumlanması ve sonuçlandırıması, Çalıșma için gerekli literatür taramasında sorumluluk almak, Çalışmanın bütününün veya önemli bölümlerinin yazımında sorumluluk almak, Yazım ve dilbilgisi dışında bilimsel olarak gönderilmeden önce makaleyi gözden geçirme.

Atıf yazım şekli / How to cite : Ertuğrul A ve Bostancı İ. Çocuklarda Ağır Astım, Biyolojik Tedaviler ve COVID-19 Pandemisinde Güncel Yaklașımlar. Türkiye Çocuk Hast Derg 2021;15:168-173.
Yazıșma Adresi / Correspondence Address:

\section{Ayșegül ERTUĞRUL}

SBÜ Dr. Sami Ulus Kadın Doğum ve Çocuk Sağlığı Hastalıkları Eğitim ve Araştırma Hastanesi,

Çocuk İmmünoloji ve Alerji Bilim Dalı, Ankara, Türkiye

E-posta: aysegull.ertugrul@gmail.com
Geliş tarihi / Received : 25.06.2020 Kabul tarihi / Accepted : 07.10.2020 Elektronik yayın tarihi $\quad: 18.03 .2021$ Online published

DOI: 10.12956/tchd.758127 


\section{GiRiş}

Astım çocukluk çağında gözlenen en sık kronik hastalıktır. On sekiz yaş altında tahmini olarak 6.1 milyon çocuğu etkilediği düşünülmektedir (1,2). Ağır astım, çocuklarda nispeten nadir görülen bir durumdur. Seçilen ağır astım tanımlama kriterlerine bağlı değişmekle birlikte çocuklarda ağır astım prevalansı astım popülasyonunun yaklaşık \%5'ni oluşturmaktadır (3). Erişkinlere kıyasla çocuklarda ağır astım daha nadir görülmesine karşın, ağır morbidite ve bazen mortaliteye neden olabilir. $(3,4)$ Çocukluk çağında gözlenen ağır astım erişkin dönemde kronik obstrüktif akciğer hastalığı gelişimi ile ilişskilidir. (5) Çocukluk çağı astımında sağık kaynakları harcamalarının yaklaşık yarısından ağır astım sorumludur $(3,4)$.

\section{Ağır astım tanımı ve epidemiyolojisi}

Ağır astım kavramını anlamak için öncelikle kontrolsüz astım ve tedavisi zor astım tanımını bilmek gerekmektedir. "Kontrolsüz astım" aşağıdaki koşulların herhangi birinin varlı̆ı̆ıda tanımlanır $(6,7)$;

- Semptomların sık olması (sık gündüz semptomları, sık kurtarıcı ilaç intiyacı, astım nedeniyle aktivite kısıtlanması, astım nedeniyle gece uyanma),astım kontrol anketinin $(A C Q) \geq 1.5$ olması, astım kontrol testinin $(A K T)<20$ olması

- Bir önceki yılda üç günden fazla sistemik kortikosteroid kullanımı gerektiren $\geq 2$ atak varığı

- Bir önceki yılda hastane yatışı gerektiren, yoğun bakım veya mekanik ventilasyon ihtiyacı duyulan astım atağı varlığı

- Uygun bronkodilatör tedavi sonrası FEV1'in (bir saniyedeki zorlu ekspiratuar hacim) <\%80 (hava akımı kısıt|lığı) olması

Uluslararası rehberlerden GINA (Global Initiative for Asthma) "tedavisi zor astımı" dördüncü ve beșinci basamak tedaviye (orta ya da yüksek doz inhale kortikosteroid ile birlikte ikinci bir kontrol edici ajan [ uzun etkili beta agonist ya da lökotrien reseptör antagonisti/teofilin]) rağmen astımı kontrolsüz olan ya da ancak bu basamaklarda kontrolü sağlanabilen astım olarak tanımlamaktadır (8).

Ağır astım tedavisi zor astımın alt grubudur. Ağır astım tanısını koymadan önce hastada astım tanısı doğrulanmalı, astım kontrolünü bozabilecek ilaç uyumu, inhalasyon tekniği, tedavi gerektiren komorbid durumlar gözden geçirildikten sonra hasta ağır astım açısından değerlendirilmelidir. GINA rehberinde "ağır astım" uygun ve doğru tedaviye rağmen, astımın kontrol altında olmaması ya da ancak yüksek doz tedavi ile kontrol altına alınabilmesi, basamak azaltıldığı durumda astım kontrolünün bozulması olarak tanımlanır (8). Avrupa Solunum Derneği (ERS) ve Amerikan Toraks Derneği (ATS) rehberlerinde ise "ağır astım" bir önceki yllda yüksek doz inhale kortikosteroid ile birlikte ikinci bir kontrol edici ajan ile kontrol altına alınabilen ve/veya bir önceki ylın $\geq \% 50$ 'sinde sistemik kortikosteroid kullanımı ile kontrol altına alınabilen ya da bu tedaviye rağmen kontrolsüz olan astım olarak tanımlanmıştır (6).

Kuzey Avrupa'da yapılan doğum kohort çalışmalarındaki veriler doğrultusunda ağır astım prevalansı her bin çocukta 2-5 olarak ya da astımlı çocuklarda \%2-5 olarak öngörülmektedir $(9,10)$. Severe Asthma Research Program (SARP) çalıșmasındaki 188 ağır astımlı çocuk ve Unbiased Biomarkers for the Prediction of Respiratory Disease Outcomes (U-BIOPRED) kohortundaki ağır astımı olan 99 çocuk incelendiğinde yaşların tipik olarak 11-12 yaş arasında dağıım gösterdiği ve \%55-60'ının erkek olduğu saptanmışıı $(4,11)$.

\section{Ağır astım yönetimi}

Tedavisi zor astım tanımına uyan hasta, zor hasta anlamına gelmez. Çoğu durumda astımın zor tedavi olmasının nedeni değiştirilebilir faktörlerdir. Katkıda bulunan; ko-morbiditeler (obezite, gastroözefageal reflü, kronik rinosinüzit, nazal polip, obstrüktif uyku apne sendromu gibi), hastanın ilaç tedavi uyumsuzluğu, uygun olmayan inhaler kullanım teknikleri ve tetikleyicilerin ortadan kaldırımaması (sigara, alerjen maruziyeti gibi) oluşturur. Ayrıca astım tanısının yanlış olabileceği öncelikle düşünülerek ayırıcı tanılar tekrar gözden geçirilmelidir (8) (Tablo I).

Ağır astım tedavisi yönetiminde ayıııcı tanılar dışlanıp, tanı doğrulandıktan sonra, semptomları ve atakları arttıran faktörler taranarak tedavi gözden geçirilmeli ve hasta için en uygun hale getirimelidir. Tedavisi düzenlenen hastanın 3-6 ayllk süre sonrası tedaviye yanıtı tekrar değerlendirilmelidir. Bu aşamada hastanın semptom kontrolü, son muayeneden itibaren atak sayısı ve gerekli tıbbi müdahaleleri, ilaç yan etkileri, inhaler teknik ve uyumu, solunum fonksiyon testi ve hastanın memnuniyet ve endişeleri ele alınır. Tüm düzenlemelere rağmen hasta kontrol altında değilse ya da yüksek doz tedaviden basamak inildiğinde şikayetleri tekrar başlyyorsa hasta ağır astım kliniğinde uzman hekim tarafından değerlendirilmelidir. Ayıııcı tanıların dışlanması için hastanın bulgularına göre belirlenen tetkikler standart tetkiklere ek olarak yapilabilir $(8,12)$ (Tablo I).

Ağır astımlı hastalarda biyolojik ajanlar ile tedaviye başlamadan önce, kullanılan mevcut tedaviye (orta/yüksek doz inhale steroid \pm uzun etkili beta agonist) ilave olarak tiotropium, lökotrien reseptör antagonisti, düşük doz makrolid tedavisi (endikasyon dışı kullanım ile) gibi alternatif tedaviler eklenerek basamak arttırlabilir. Düşük dozda ek oral kortikosteroid tedavisi kullanılabilir. Sistemik kortikosteroid tedavisi yan etkiler nedeniyle dikkatli kullanılmalıdır, yan etkileri azaltmak için gün așırı uygulama yapılabilir. Eklenen alternatif tedavilere klinik yanıt alınamadığında bu tedaviler basamak azaltılarak dikkatlice kesilmelidir. Eğer kullanıldıysa basamak azaltırken öncelikle sistemik kortikosteroid tedavisinden bașlanmalıdır. Bronșiyal termoplasti erişkinlerde diğer bir seçenek olmakla birlikte 
Tablo I: Ağır astımda ayıııcı tanı ve tanısal değerlendirme (13).

\section{Ayırıcı tanı}

Vokal kord disfonksiyonu

Trakeobronkomalazi

Trakeoözefageal fistül

vasküler halka

Mediastinal kitle

Kistik fibrozis

Primer silier diskinezi

Bronşektazi

Uzamış bakteriyel bronşit

Tüberküloz

Bronșiolitis obliterans

Bronkopulmoner displazi

Hipogamaglobulinemi

Yabancı cisim aspirasyonu

Konjenital kalp hastalıkları

Panik atak
Tanısal tetkikler

\section{Ağır astımı olan tüm çocuklarda standart değerlendirme}

Solunum fonksiyon testi (reverzibilite)

Hemogram ve hücre sayımı

Total lgE

Deri prik testi ya da spesifik lgE

Hastaya özel durumlarda yapılacak ilave değerlendirmeler

Akciğer volümlerinin ölçümü

Ter testi

$\lg A, \lg \mathrm{g}, \lg \mathrm{M}$

Balgam indüksiyonu ve yayması

Akciğer bilgisayarlı tomografi

Sinüs bilgisayarlı tomografi

Fleksible bronkoskopi

Direkt laringoskopi

Özefagogastroduodenoskopi uzun vadede güvenli olduğuna dair kanitlar kısıtlıdır. Bronşiyal termoplasti tedavisi 18 yaş altında uygulanmamaktadır $(8,12)$.

Ağır astımda farklı mekanizmalar rol oynadığı için farklı fenotipler söz konusu olup tedavi hastaya göre kişiselleștirilmelidir. Günümüzde astım tek bir kavram olarak kabul edilmemekte, birçok iç ve dış etken ile modifiye olan, birbiri ile etkileşim halinde immün-inflamatuar yolaklardan olușan karmașlk bir biyolojik ağ modeli olduğu düşünülmektedir (13-15). Ağır astım için majör immün-inflamatuar yolakları tip 2 yüksek, tip 2 düşük ve karma endotipler olușturmaktadır. Bu yolaklar belirli genetik, epigenetik, metabolik, nörojenik ve remodelling özelliklere sahip olabilirler $(16,17)$. Ağır astım hastalarının yaklaşık yarısında tip 2 inflamasyon gözlenir. Tip 2 inflamasyon, alerjenlerin adaptif immün sistem tarafindan tanınması ile üretilen IL-4, IL-5 ve IL-13 gibi sitokinlerle karakterizedir. Doğal bağıșıklık sistemini, IL-33, IL-25, timik stromal lenfopoetin üretimiyle stimüle eden virüsler, bakteriler ve irritanlar tarafindan da tetiklenir. Tip 2 inflamasyon genelde eozinofili ya da fraksiyonel ekshale nitrik oksit (FeNO) artışı ile karakterizedir ve genellikle atopi eşlik eder. Non tip 2 inflamasyonda karakteristik olarak nötrofiller görülür (18). Çocuklarda erișkinlere kıyasla endotip ve ilișkili biyobelirteçlerle ilgili daha az bilgi bulunmaktadır. Çocuklarda yapılan çalışmalarda ağır astım, çoklu aeroalerjen duyarlığı, alerjik rinit, besin alerjisi, eozinofilik hava yolu inflamasyonu, sigara dumanı maruziyeti ve hava yolu remodellingi ile ilișkilendirilmiștir $(19,20)$.

Hastanın ağır astım fenotipine katkıda bulunan faktörlerin değerlendirilmesi sonucunda tip 2 astım olduğu belirlenen hastalara biyolojik tedavilerin uygulaması günümüzde ağır astım tedavisi yönetiminde önemli bir gelişme sağlamıştır (21). Non tip 2 astımda biyolojik tedavi mevcut değildir (8) . Hasta yüksek doz inhale kortikosteroid ya da günlük oral kortikosteroid alırken kan eozinofilleri $\geq 150 / \mu$ l ve/veya FeNO $\geq 20 p p b$ ve/ veya balgam eozinofilleri $\geq \% 2$ ise ve/veya hastada atopik astım olması durumunda dirençli tip 2 inflamasyon intimali gözönünde bulundurulmalıdır (8). Ağır astımı olan çocukta tip 2 hedefli biyolojik tedavi bașlanılması düșünülüyorsa özellikle endemik bölgelerde kan eozinofilisine parazit enfeksiyonlarının yol açabileceği hatırlanmalı ve parazit enfeksiyonları için hasta değerlendirilmelidir. Parazit enfeksiyonu varlığında bașlanan tip 2 hedefli tedavi paraziter hastalığın ilerlemesine neden olabilir (21).

\section{Ağır astımda kullanılan biyolojik tedaviler}

Uluslararası rehberler tarafından 18 yaș altında kullanımı önerilen biyolojik ajanları omalizumab, mepolizumab, benralizumab ve dupilumab olușturur $(8,6,21)$. Tip 2 hedefli biyolojik tedavileri seçerken, hastanın uygunluğu ve iyi yanıtı ön gören faktörlerin varlığı dışında, ulusal geri ödeme kriterlerinin karşılanıp karşlanmaması, maliyet ve hasta tercihi de göz önünde bulundurulmalıdır (8). Biyolojik tedavilerin depolanması, uygulama ve uygulama sonrası izlem süresi konusunda üreticinin talimatları takip edilmelidir (21).

Anti-IgE antikoru omalizumab, ağır astımı olan 6-11 yaş arası çocuklarda 2009 yllından beri, daha büyük çocuklar ve erișkinlerde ise 2003 yllından beri kullanılmaktadır (3). Omalizumab, serbest IgE'nin Fc parçasına bağlanarak IgE'nin FcER1 reseptörlerine bağlanmasını engeller ve reseptör ekspresyonunun azalmasını sağlar. Plazmasitoid dendritik hücreler üzerinde IgE reseptörü çapraz bağlanması, antiviral aktiviteyi baskilamaktadır. Bu nedenle, omalizumab uygulamasını takiben plazmasitoid dendritik hücreler üzerinde IgE reseptörlerinin azalması ve dolaşımdaki azalmış lgE, antiviral bağışıklık tepkilerini güçlendirebilir $(3,21)$. Mepolizumab ve benralizumab 12 yaș üstünde kullanilan anti-IL-5 ajanlardır. IL-5'in reseptörüne bağlanmasının engellenmesi ile eozinofillerin maturasyonu ve farkllașması bloke olur (20). AntiIL-4Ra monoklonal antikoru dupilumab da 12 yaș üstünde kullanılmaktadır. IL-4 reseptör a subünitesine bağlanır; IL-4 ve IL-13 yolağını birlikte inhibe eder. Tablo I'de biyolojik ajanların 
Tablo II: Çocuklarda ağır astım tedavisinde kullanılan biyolojik ajanlar $(9,7,21)$.

\begin{tabular}{|c|c|c|c|}
\hline İlaç & $\begin{array}{c}\text { Uygun popülasyon } \\
\text { (Son bir yılda belirtilen sayının üstünde } \\
\text { astım alevlenmesi ile birlikte) }\end{array}$ & İyi yanıtı öngören faktörler & Klinik sonuçlar \\
\hline $\begin{array}{l}\text { Anti-IgE } \\
\text { Omalizumab }\end{array}$ & $\begin{array}{l}\text { Orta-ağır alerjik astım } \\
\geq 6 \text { yaş } \\
\text { Pereniyal aeroalerjen duyarılı̆̆ı } \\
\text { Serum IgE 30-1500 IU/ml }\end{array}$ & $\begin{array}{l}\text { Kan eozinofil sayısı } \geq 260 / \mu l \\
\text { FeNO } \geq 20 \text { ppb } \\
\text { CCocuklukta bașlayan astım } \\
\text { Alerjen ile tetiklenen klinik }\end{array}$ & $\begin{array}{l}\text { Astım ataklarında } \downarrow \\
\text { Semptomlarda } \downarrow \\
\text { Yaşam kalitesinde } \uparrow \\
\text { IKS dozunda } \downarrow \\
\text { Kurtarıc ilaç kullanımında } \downarrow \\
6 \text { - } 11 \text { yaş arası viral } \\
\text { enfeksiyonlarla indüklenen } \\
\text { ataklarda } \downarrow\end{array}$ \\
\hline $\begin{array}{l}\text { Anti-IL-5/IL-5R } \\
\text { Mepolizumab / } \\
\text { Benralizumab }\end{array}$ & 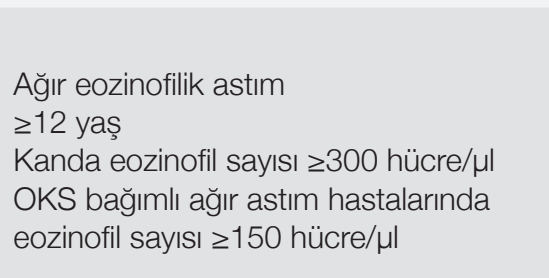 & $\begin{array}{l}\text { Yüksek kan eozinofil sayısı } \\
\text { Bir önceki yılda çok sayıda ağır } \\
\text { atak } \\
\text { Erişkin çağda başlayan astım } \\
\text { Nazal polipozis } \\
\text { Bașlangıçta idame tedavi olarak } \\
\text { OKS kullanıırıyor olması }\end{array}$ & $\begin{array}{l}\text { Astım ataklarında } \downarrow \\
\text { Semptomlarda } \downarrow \\
\text { Yaşam kalitesinde } \uparrow \\
\text { FEV1 } \uparrow \\
\text { OKS dozunda } \downarrow\end{array}$ \\
\hline $\begin{array}{l}\text { Anti-IL4Ra } \\
\text { Dupilumab }\end{array}$ & $\begin{array}{l}\text { Ağır eozinofilik astım, ağır tip2 astım } \\
\geq 12 \text { yaş } \\
\text { Kanda eozinofil sayısı } \geq 300 / \mu l \\
\text { FeNO } \geq 25 \text { ppb } \\
\text { OKS idame tedavisine intiyaç }\end{array}$ & $\begin{array}{l}\text { Yüksek kan eozinofil sayısı } \\
\text { Yüksek FeNO }\end{array}$ & $\begin{array}{l}\text { Astım ataklarında } \downarrow \\
\text { Semptomlarda } \downarrow \\
\text { Yaşam kalitesinde } \uparrow \\
\text { FEV1 } \uparrow \\
\text { OKS dozunda } \downarrow\end{array}$ \\
\hline
\end{tabular}

IKS: Inhale kortikosteroid, OKS: Oral kortikosteroid, FeNO: Fraksiyonel ekshale nitrik oksit

uygunluk kriterleri, iyi yanıtı öngören faktörler ve klinik faydaları gösterilmiştir $(3,21)$.

Avrupa Alerji ve Klinik İmmünoloji Akademisi (EAACl) ağır astımda ko-morbiditeler varlığında tercih edilebilecek biyolojik ajanları rehberinde sunmaktadır. Buna göre kronik sinüzit ve nazal polip varlığında anti-IL-5 ajanlar veya dupilumab, atopik dermatit varlığında dupilumab, kronik ürtiker, alerjik rinit veya besin alerjisi varlığında omalizumab tercih edilebilir (21).

Hastaya biyolojik ajanlar başlandıktan sonra tedavi yanıtı 4 ay içinde değerlendirilmelidir. Ağır astımda biyolojik tedaviye iyi yanıt kriterleri net değildir. Ancak bunun için hasta semptom kontrolü, atak sıklığı, intiyaç duyduğu tedavi yoğunluğu, solunum fonksiyon testleri ile ilaç yan etkileri ve hasta memnuniyeti değerlendirilmelidir $(8,21)$. Biyolojik ajana yanıt yoksa tedavi durdurulmalı ve hasta fenotipi tekrar değerlendirilmelidir. Yanıt belirsizse tedavi 6-12 aya kadar uzatılabilir. lyi yanıt alınan hastalar, her üç ile altı ayda bir kontrol edilmelidir. Bu hastalarda hastanın klinik bulguları ve tercihi doğrultusunda almakta olduğu tedaviler azaltılarak kademeli olarak kesilebilir. Oral tedavilerden ilk olarak kortikosteroid tedavisinin kesilmesine öncelik verilmelidir. İnhale tedavilerden inhale kortikosteroid dozunu azaltmak düşünülebilir ama bu tedavinin tamamen kesilmesi önerilmez. Bu konudaki ortak görüş en azından orta doz inhale kortikosteroide devam etmek şeklindedir $(3,8,21)$. Biyolojik ajanların ne zaman ve nasıl kesileceğine dair veriler kısıtlı olmakla birlikte, en az bir ylllik tedaviden sonra, astım kontrolü orta doz inhale kortikosteroid ile sağlanabiliyorsa ve atopik astımda ortaya konan alerjene maruziyet ortadan kalkmışsa biyolojik tedavinin kesilmesi denenebilir. Biyolojik tedavilere ne kadar süre devam edileceği ile ilgili kısıtlı sayıda çalışma mevcuttur. Tedavi kesildikten sonra kötüleșme veya ataklar ortaya çıkabilir $(8,21)$.

\section{Covid-19 Pandemisinde ağır astım ve biyolojiklerin kullanımı}

COVID-19 (Koronavirüs hastalığı 2019) hastalığı ve pandemisi sırasında ağır astımın yönetimi, özellikle oral kortikosteroidlerin kullanımı ile güvenlik endişeleri olması nedeniyle zorlayıcı bir durumdur. Biyolojik tedavilerdeki son gelișmeler ve kullanımlarının onaylanması, ağır astımda umut verici ve daha kişiselleştirilmiş bir tedavi seçeneği sunmasına rağmen, SARS-CoV-2 (Şiddetli Akut Solunum Sendromu-Koronavirus-2) enfeksiyonu sırasında mevcut güvenlik durumları tamamen bilinmemektedir (22). Astım hastalarının SARS-CoV-2 ile enfekte olma riskinin daha yüksek olduğuna dair açık bir kanıt yoktur, ancak ABD'den gelen son raporlar astımın COVID-19 olan çocuklarda ve yetișkinlerde Çin ve Avrupa'da daha önce bildirildiğinden çok daha yaygın olduğunu düşündürmektedir (23-25).

COVID-19 pandemisi döneminde astımı olan hastalarda inhale kortikosteroidlerin güvenliği hakkındaki anlayışı değiştiren ilgili veriler ortaya çıkmadıkça, klinisyenler semptom kontrolünü sağlamak ve alevlenmeleri önlemek için mevcut kanıta dayalı yönergelerin tavsiyelerine uymalıdır (7).

Biyolojikler, diğer tedavilerle kontrol altına alınamamış ağır astımda kullanılan tedavilerdir. Genel olarak güvenli kabul 
edilmelerine karşın, uzun dönem güvenlik çalsşmaları birkaç yıl ile sinırıdır $(7,22)$. COVID-19'un patogenezinde tip 2 inflamasyon yanıtlarının rolü henüz tam olarak belirlenememiştir. Bu nedenle hastaların, tip 2 alerjik yanıt yollarını hedef alan biyolojikler konusunda rehberlik için veriler kısıtıdır (26). Ağır COVID-19 hastalarında "sitokin firtınası" ile ilişkili olarak organ hasarı, özellikle akut respiratuar distres sendromu, akut böbrek ve karaciğer hasarı, miyokardit ve disemine intravaskuler koagulasyon gözlenebilir. Bu durum tip1 ve tip3 proinflamatuar sitokinlerin normalin çok üstünde artışı ile ilişkilidir. Bu tip 1 ve tip 3 aracil inflamatuar yanıtlar potansiyel olarak anti-inflamatuar sitokinler olan IL-10 ve TGF- $\beta$ gibi sitokinlerin yanı sıra potansiyel olarak tip 2 cevaplarla ile dengelenir $(27,28)$.

Biyolojik ajanlarla tedavi edilen hastalarda SARS-CoV-2'ye karşı immün yanıtın bozulduğunu gösteren hiçbir kanıt yoktur. COVID-19 pandemisinde, potansiyel bir zararı gösteren veri gözlenmediği takdirde, uygun kriterlere sahip ve biyolojik tedavilere iyi yanıt veren hastalarda bu tedavilerin uygulamasına devam edilmesi tavsiye edilmektedir (22, 26, 29-32). COVID-19 salgını sırasında sosyal mesafe herkes için teşvik edilmeli ve mümkün ise biyolojikler evde uygulanmalıdır (26).

Astımlı hastalarda omalizumab, mepolizumab, benralizumab ve dupilumab ile günümüze kadar yapılan plasebo kontrollü çalışmalarda enfeksiyon duyarlıı̆ında artış veya immünsüpresif etki bildirilmemiştir. Omalizumab için ayrıca muhtemel anti-viral etki söz konusudur (22). Biyolojik tedavileri durdurmak, atak riskinin artmasına, oral kortikosteroid kullanımının artmasına ve SARS-CoV-2 maruziyeti / enfeksiyonu için risk faktörü olan acil servise başvuru ve hastanede kalma olasılığının artmasına neden olabilir. Bu nedenle, maliyetler ve faydalar dengelenirken, COVID-19 olmayan ağır astımı olan hastalar için mevcut pandemi sırasında biyolojik tedavinin kesilmesi önerilmez (22).

Ağır astımı olup biyolojik ajanlarla tedavi edilen hasta aktif SARS-CoV-2 enfeksiyonu geçirirse kullanılan biyolojik tedaviye ara verilmelidir. Bu durumda hastanın tedavisine diğer kontrol edici ilaçlar ile devam edilir. Hastalık düzeldikten sonra (SARSCoV-2 testinin negatifleșmesi ile) en az 2 haftalık bir süre sonra kullanılan biyolojik ajan tekrar başlanabilir (26).

\section{KAYNAKLAR}

1. National Survey of Children's Health. NSCH 2011/12. Data query from the Child and Adolescent Health Measurement Initiative, Data Resource Center for Child and Adolescent Health website. Available from: https://www.childhealthdata.org/learn-about-thensch/NSCH. Aaccessed 23 June 2020.

2. Centers for Disease Control and Prevention. National Center for Health Statistics. National Health Interview Survey, 2016. Analysis by the American Lung Association Epidemiology and Statistics Unit using SPSS software. Available from: https://www.cdc.gov/nchs/ nhis/methods.htm. Aaccessed 23 June 2020.
3. Ahmed $\mathrm{H}$, Turner $\mathrm{S}$. Severe asthma in children-a review of definitions, epidemiology, and treatment options in 2019. Pediatr Pulmonol 2019;54:778-87.

4. Fleming L, Murray C, Bansal AT, Hashimoto S, Bisgaard H, Bush A, et al. The burden of severe asthma in childhood and adolescence: results from the paediatric U-BIOPRED cohorts. Eur Respir $J$ 2015;46:1322-33.

5. Selby L, Saglani S. Severe asthma in children: therapeutic considerations.Curr Opin Allergy Clin Immunol 2019;19:132-40.

6. Chung KF, Wenzel SE, Brozek JL, Bush A, Castro M, Sterk PJ, et al. International ERS/ATS guidelines on definition, evaluation and treatment of severe asthma. Eur Respir J 2014;43:343-73.

7. 2020 GINA Maın Report. 2020 GINA Report, Global Strategy for Asthma Management and Prevention. Available from: https:// ginasthma.org/gina-reports/. Aaccessed 23 June 2020.

8. Diffucult-to-treat and severe asthma in adolescent and adult patients Diagnosis and Management. GINA 2019. Available from: https://ginasthma.org/severeasthma/. Aaccessed 23 June 2020.

9. Nordlund B, Melen E, Schultz ES, Gronlund H, Hedlin G, Kull I. Prevalence of severe childhood asthma according to the WHO. Respir Med 2014;108:1234-7.

10. Lang A, Carlsen KH, Haaland G, Devulapalli CS, Munthe-Kaas M, Mowinckel $P$, et al. Severe asthma in childhood: assessed in 10 year olds in a birth cohort study. Allergy 2008;63:1054-60.

11. Teague WG, Phillips BR, Fahy JV, Wenzel SE, Fitzpatrick AM, Moore WC, et al. Baseline Features of the Severe Asthma Research Program (SARP III) Cohort: Differences with Age.J Allergy Clin Immunol Pract 2018;6:545-54.e4.

12. Barsky EE, Giancola LM, Baxi SN, Gaffin JM. A Practical Approach to Severe Asthma in Children. Ann Am Thorac Soc 2018;1:399408.

13. Anderson GP. Endotyping asthma: new insights in to key pathogenic mechanisms in a complex, heterogeneous disease. Lancet 2008;372:1107-19.

14. Chung KF, Adcock IM. Precision medicine for the discovery of treatable mechanisms in severe asthma. Allergy 2019;74:1649-59.

15. Can D. Can Phenotypes be Recognized? Izmir Dr Behçet Uz Çocuk Hast Dergisi 2019;9:167-74.

16. Agache I. Severe asthma phenotypes and endotypes. Semin Immunol 2019;46:101301.

17. Lötvall J, Akdis CA, Bacharier LB, Bjermer L, Casale TB, Custovic $A$, et al. Asthma endotypes: a new approach to classification of disease entities within the asthma syndrome. J Allergy Clin Immunol 2011;127:355-60.

18. Israel E, Reddel HK. Severe and Difficult-to-Treat Asthma in Adults. N Engl J Med 2017;377:965-76.

19. Pongracic JA, Krouse RZ, Babineau DC, oratti EM, Cohen RT, Wood RA, et al. Distinguishing characteristics of difficult-to-control asthma in inner-city children and adolescents. J Allergy Clin Immunol 2016;138:1030-41.

20. Liu AH, Babineau DC, Krouse RZ, Zoratti EM, Pongracic JA, O'Connor GT, et al. Pathways through which asthma risk factors contribute to asthma severity in inner-city children. J Allergy Clin Immunol 2016;138:1042-50.

21. Agache I, Akdis C, Akdis M, Canonica GW, Casale T, Chivato T, et al. EAACI Biologicals Guidelines - Recommendations for severe asthma [published online ahead of print, 2020 Jun 2]. Allergy 2020;10.1111/all.14425. 
22. Morais-Almeida M, Aguiar R, Martin B, Ansotegui IJ, Ebisawa M, Arruda LK, et al. COVID-19, asthma, and biologic therapies: What we need to know World Allergy Organ J 2020;13:100126.

23. Halpin DMG, Faner R, Sibila O, Badia JR, Agusti A. Do chronic respiratory diseases or their treatment affect the risk of SARSCoV-2 infection?. Lancet Respir Med 2020;8:436-8.

24. Li X, Xu S, Yu M, Wang K, Tao Y, Zhou Y, et al. Risk factors for severity and mortality in adult COVID-19 inpatients in Wuhan. J Allergy Clin Immunol 2020;146:110-8.

25. Hospitalization Rates and Characteristics of Patients Hospitalized with Laboratory-Confirmed Coronavirus Disease 2019 COVID-NET, 14 States, March 1-30, 2020Weekly / April 17, 2020;69:458-464. On April 8, 2020, this report was posted online as an MMWR Early Release. Available from: https://www.cdc.gov/ mmwr/volumes/69/wr/mm6915e3.htm. Aaccessed 23 June 2020.

26. Vultaggio A, Agache I, Akdis CA, Akdis M, Bavbek S, Bossios A, et al. Considerations on Biologicals for Patients with allergic disease in times of the COVID-19 pandemic: an EAACI Statement. Allergy 2020;10.1111/all.14407.

27. Huang C, Wang Y, Li X, Ren L, Zhao J, Hu Y, et al. Clinical features of patients infected with 2019 novel coronavirus in Wuhan, China. Lancet 2020;395:497-506.
28. Sabogal Piñeros YS, Bal SM, Dijkhuis A, Majoor CJ, Dierdorp BS, Dekker T, et al. Eosinophils capture viruses, a capacity that is defective in asthma. Allergy 2019;74:1898-909.

29. COVID-19: GINA Answers to Frequently Asked Questions on asthma Management Release date: March 25, 2020 Follow GINA at @ginasthma. Available from: https://ginasthma.org/wpcontent/uploads/2020/03/Final-COVID-19-answers-to-frequentquestions-25.3.2020-1.pdf. Aaccessed 23 June 2020.

30. Important information about COVID-19 for those with asthma. From the American College of Allergy, Asthma and Immunology. ARLINGTON HEIGHTS, III (March 12, 2020) Available from: https://acaai.org/news/important-information-about-covid-19those-asthma. Aaccessed 23 June 2020.

31. Important information about COVID-19 for those with asthma. From the American College of Allergy, Asthma and Immunology. ARLINGTON HEIGHTS, III (March 12, 2020). Available from: https://acaai.org/news/important-information-about-covid-19those-asthma. Aaccessed 23 June 2020.

32. COVID-19: information for the respiratory community. Available from: https://www.brit-thoracic.org.uk/about-us/covid-19information-for-the-respiratory-community/. Aaccessed 23 June 2020 